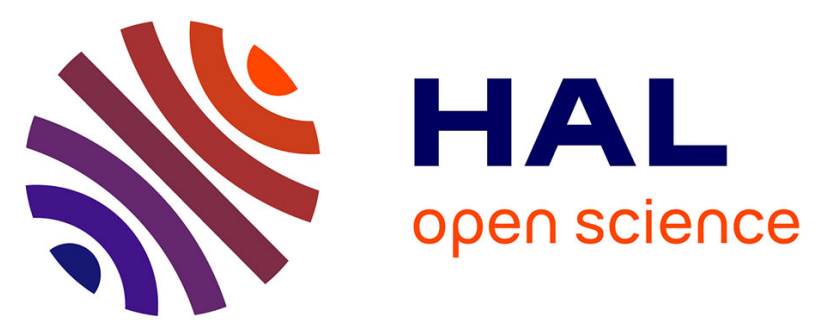

\title{
Coordination capacity of Keggin anions as polytopic ligands: case study of [ $\mathrm{VNb} 12 \mathrm{O} 40$ ] 15
}

Anna A Mukhacheva, Victoria V Volcheck, Dmitry G Sheven, Vadim V Yanshole, Nikolay B Kompankov, Mohamed Haouas, Pavel A Abramov, Maxim N Sokolov

\section{To cite this version:}

Anna A Mukhacheva, Victoria V Volcheck, Dmitry G Sheven, Vadim V Yanshole, Nikolay B Kompankov, et al.. Coordination capacity of Keggin anions as polytopic ligands: case study of [VNb $12 \mathrm{O}$ 40 ] 15. Dalton Transactions, 2021, 50 (20), pp.7078-7084. 10.1039/D1DT00765C . hal-03238220

\section{HAL Id: hal-03238220 https://hal.science/hal-03238220}

Submitted on 27 May 2021

HAL is a multi-disciplinary open access archive for the deposit and dissemination of scientific research documents, whether they are published or not. The documents may come from teaching and research institutions in France or abroad, or from public or private research centers.
L'archive ouverte pluridisciplinaire HAL, est destinée au dépôt et à la diffusion de documents scientifiques de niveau recherche, publiés ou non, émanant des établissements d'enseignement et de recherche français ou étrangers, des laboratoires publics ou privés. 


\section{Coordination capacity of Keggin anions as polytopic ligands: case study of $\left[\mathrm{VNb}_{12} \mathrm{O}_{40}\right]^{15-}$}

Received 00th January 20xx, Accepted 00th January 20xx

DOI: $10.1039 / x 0 \times x 00000 x$
Anna A. Mukhacheva, ${ }^{a}$ Victoria V. Volcheck, ${ }^{a}$ Dmitry G. Sheven, ${ }^{\text {a }}$ Vadim V. Yanshole,,${ }^{\mathrm{b}, \mathrm{c}}$ Nikolay B.

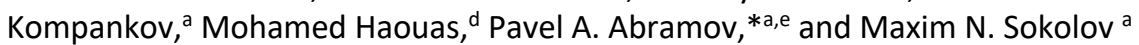

Reaction of $\mathrm{Na}_{9} \mathrm{H}_{4}\left[\mathrm{VNb}_{12} \mathrm{O}_{40}\left\{\mathrm{NbO}\left(\mathrm{CO}_{3}\right)\right\}_{2}\right]$ with $\left[\left(\mathrm{C}_{6} \mathrm{H}_{6}\right) \mathrm{RuCl}_{2}\right]_{2}$ (molar ratio $\left.\left\{\mathrm{VNb}_{12}\right\}:\left\{\left(\mathrm{C}_{6} \mathrm{H}_{6}\right) \mathrm{Ru}\right\}=1: 4\right)$ in aqueous solution gives a mixture of $\left[\alpha-\left\{\left(\mathrm{C}_{6} \mathrm{H}_{6}\right) \mathrm{Ru}\right\}_{4} \mathrm{VNb}_{12} \mathrm{O}_{40}\right]^{7-}$ and $\left[\alpha-\left\{\left(\mathrm{C}_{6} \mathrm{H}_{6}\right) \mathrm{Ru}_{3} \mathrm{VNb}_{12} \mathrm{O}_{40}\right]^{9-}\right.$. Direct acetone diffusion into mother liquor leads to crystallization of $\mathrm{Na}_{6} \mathrm{H}\left[\alpha-\left\{\left(\mathrm{C}_{6} \mathrm{H}_{6}\right) \mathrm{Ru}\right\}_{4} \mathrm{VNb}_{12} \mathrm{O}_{40}\right] \cdot 41.25 \mathrm{H}_{2} \mathrm{O}(1)$, characterized by single crystal x-ray diffraction (SCXRD). This anion has four organometallic fragments asymmetrically coordinated to the $\alpha$-Keggin type $\left[\mathrm{VNb}_{12} \mathrm{O}_{40}\right]^{15-}$ backbone. Three $\left\{\left(\mathrm{C}_{6} \mathrm{H}_{6}\right) \mathrm{Ru}\right\}^{2+}$ groups cap triangular faces and one group a rectangular face of $\left[\mathrm{VNb}_{12} \mathrm{O}_{40}\right]^{15-}$. Equilibrated mixture of [ $\alpha-$ $\left.\left\{\left(\mathrm{C}_{6} \mathrm{H}_{6}\right) \mathrm{Ru}\right\}_{4} \mathrm{VNb}_{12} \mathrm{O}_{40}\right]^{7-}$ and $\left[\alpha-\left\{\left(\mathrm{C}_{6} \mathrm{H}_{6}\right) \mathrm{Ru}\right\}_{3} \mathrm{VNb}_{12} \mathrm{O}_{40}\right]^{9-}$ was studied by ${ }^{1} \mathrm{H}$ DOSY NMR, HPLC-ICP-AES and HPLC-ESI-MS combined techniques. Direct chromatographic separation of these complexes results in unexpected transformation of both species into $\left[\alpha-\left\{\left(\mathrm{C}_{6} \mathrm{H}_{6}\right) R u\right\}_{5} \mathrm{VNb}_{12} \mathrm{O}_{40}\right]^{5-}$, isolated and characterized as $\mathrm{Na}_{5}\left[\alpha-\left\{\left(\mathrm{C}_{6} \mathrm{H}_{6}\right) \mathrm{Ru}_{5} \mathrm{VNb}_{12} \mathrm{O}_{40}\right] \cdot 16 \mathrm{H}_{2} \mathrm{O}\right.$ (2). This anion contains five symmetrically coordinated organometallic groups occupying both triangular and rectangular faces.

\section{Introduction}

Functionalization of polyoxometalates (POMs) and POM-based architectures is one of the most important and challenging goals in the chemistry of polyoxoanions, opening wide prospects to design POM-based materials for applications in materials science, catalysis, biomedicine etc. One of the most common ways to modify the "surface" of POM, is to achieve direct covalent attachment of functional groups with specific affinities that enable anchoring POMs on the surface of carbon materials, gold nanoparticles and other supports. ${ }^{1-3}$ Another approach is to graft additional heterometals with coordinated functional groups. ${ }^{4}$ In this case catalytic performances of the POM can be enhanced by introduction of a heterometal with its specific electronic structure. In particular, noble metals combined with polyoxoanions were found to be good photo- and electrocatalysts (e.g., for water splitting).5,6 The most studied complexes in this family are polymolybdates and polytungstates with grafted umbrella-like organometallic fragments like $\left\{C p^{*} M\right\}^{2+}(M=R u, R h, I r),\{(\operatorname{cod}) M\}^{+}(M=R h, I r),\{(\text { arene }) M\}^{2+}(M$ $=\mathrm{Ru}, \mathrm{Os}) .{ }^{7}$ We shall define such polyoxoanions as hybrid organometallic-POM anions and the term "hybrid" will be used in the text.

\footnotetext{
a. Nikolaev Institute of Inorganic Chemistry, 3 Akad. Lavrentiev Ave. 630090, Russia; b. International Tomography Center, Institutskaya str. 3a, 630090, Novosibirsk, Russia;

Novosibirsk State University, Pirogova str. 1, 630090, Novosibirsk, Russia;.

d. Institut Lavoisier de Versailles, UMR 8180 CNRS, Université Paris-Saclay,, 45 avenue des Etats-Unis, 78035 Versailles, France

e. South Ural State University, Prospekt Lenina, 76, 454080, Chelyabinsk, Russia.

+ Footnotes relating to the title and/or authors should appear here.

Electronic Supplementary Information (ESI) available: [Experimental part, SCXRD data, HPLC-ESI-MS, HR-ESI-MS data,]. See DOI: 10.1039/x0xx00000x
}

A pre-requisite for POMs behaving as good ligands is a high negative charge density on the POM. Among group 6 POMs, this favorable situation can be achieved only for lacunary derivatives, exhibiting high basicity. For example, easily available hexametalates $\left[\mathrm{M}_{6} \mathrm{O}_{19}\right]^{2-}(\mathrm{M}=\mathrm{Mo}, \mathrm{W})$ could not act as ligands and are used only as non-coordinating anions for stabilization of the cationic complexes with labile ligands, e.g., in $\left[\mathrm{Re}_{2}\left(\mathrm{CH}_{3} \mathrm{CN}\right)_{10}\right]\left[\mathrm{Mo}_{6} \mathrm{O}_{19}\right]_{2 .}{ }^{8}$ By contrary, the hexaniobates and hexatantalates $\left[\mathrm{M}_{6} \mathrm{O}_{19}\right]^{8-}$ are much more basic and readily coordinate $\mathrm{d}^{6}-\mathrm{C}_{3 \mathrm{v}}$ organometallic units such as $\left\{\mathrm{M}(\mathrm{CO})_{3}\right\}^{+}$, $\{(\text { arene }) \mathrm{Ru}\}^{2+}, \quad\left\{\mathrm{Cp}{ }^{*} \mathrm{M}\right\}^{2+} .{ }^{9-12}$ In some cases grafting of organometallic fragments on the $\mathrm{Nb}$ and Ta hexametalates induces unexpected dimerization of the Lindqvist anions with the formation of $\left[\left(\mathrm{M}_{6} \mathrm{O}_{18}\right)_{2}(\mu-\mathrm{O})\right]^{14-}$ moieties. ${ }^{10,13}$ The coordination also reduces the basicity of the POM and makes it more tolerant to moderately basic media thus increasing the $\mathrm{pH}$ window for further chemical transformations. Moreover, the enhanced solubility of hybrid group 5 based anions in $\mathrm{MeOH}$ is also remarkable. ${ }^{14}$

One of the possibilities to increase the basicity of Keggin type POMs without lacunarization is multielectron reduction with the retention of the Keggin structure, e.g., reduction of $\left[\mathrm{PMO}_{12} \mathrm{O}_{40}\right]^{3-}$ to $\left[\mathrm{PMo}_{12} \mathrm{O}_{40}\right]^{5-}$ or to even more negative species, that increases the ability of coordinating various heterometals. ${ }^{15,16}$ Another possibility, which still needs to be explored, is to use Keggin anions with $\mathrm{X}^{2+}$ hetroatoms, such as $\left[\mathrm{BeW}_{12} \mathrm{O}_{40}\right]^{6-} .{ }^{17}$ However, sometimes this synthetic approach is thwarted due to the competition between the central heteroatom and the heterometal addenda in the metalate backbone, and may produce unexpected results. ${ }^{18-20}$ In this respect, the heteropolyniobates with Keggin structure $\left[\mathrm{XNb}_{12} \mathrm{O}_{40}\right]^{\mathrm{n}-}, 21,22$ with their inherently very high negative charge, are much better well-suited for coordination. However, 
possibilities for functionalization and reactivity of such "sticky" polyniobates remain virtually unexplored. There are a few reported examples of grafting a heterometal onto $\left[\mathrm{XNb}_{12} \mathrm{O}_{40}\right]^{\mathrm{n}-}$. Thus, vanado- and phosphododecaniobates can coordinate two $\mathrm{VO}^{3+}$ or $\mathrm{Sb}^{3+}$ capping cations with the formation of $\left[\mathrm{XNb}_{12} \mathrm{O}_{40}(\mathrm{VO})_{2}\right]^{9-23-25}$ and $\left[\mathrm{PNb}_{12} \mathrm{O}_{40} \mathrm{Sb}_{2}\right]^{9-} .^{26}$ In some cases such complexes (with $\mathrm{Si}, \mathrm{Ge}, \mathrm{P}, \mathrm{As}$ and $\mathrm{V}$ as central heteroatom $\mathrm{X}$ ) can be further linked with square planar $\left\{\mathrm{Cu}(\mathrm{en})_{2}\right\}^{2+}$ fragments with the formation of coordination polymers. ${ }^{27}$

\section{Results and discussion}

\section{Synthesis and structure}

Recently we published a straightforward way to prepare $\mathrm{Na}_{9} \mathrm{H}_{4}\left[\mathrm{VNb}_{12} \mathrm{O}_{40}\left\{\mathrm{NbO}\left(\mathrm{CO}_{3}\right)\right\}_{2}\right] \cdot 34 \mathrm{H}_{2} \mathrm{O},{ }^{28}$ which was found to be a good starting material for developing the chemistry of Keggin dodecaniobates. In this research the reaction of $\mathrm{Na}_{9} \mathrm{H}_{4}\left[\mathrm{VNb}_{12} \mathrm{O}_{40}\left\{\mathrm{NbO}\left(\mathrm{CO}_{3}\right)\right\}_{2}\right] \cdot 34 \mathrm{H}_{2} \mathrm{O}$ with $\left[\left(\mathrm{C}_{6} \mathrm{H}_{6}\right) \mathrm{RuCl}_{2}\right]_{2}$ taken in the molar ratio of $\left\{\mathrm{VNb}_{12}\right\}:\left\{\left(\mathrm{C}_{6} \mathrm{H}_{6}\right) \mathrm{Ru}\right\}=1: 4$ was studied (The experimental data are collected in Supporting Information). Slow diffusion of acetone vapor into the reaction mixture deposits a mixture of brown solid and orange-yellow crystals, which were studied by single crystal $x$-ray diffraction (Table S1). In the crystal structure of $\mathrm{Na}_{6} \mathrm{H}\left[\left\{\left(\mathrm{C}_{6} \mathrm{H}_{6}\right) \mathrm{Ru}\right\}_{4} \mathrm{VNb}_{12} \mathrm{O}_{40}\right] \cdot 41.25 \mathrm{H}_{2} \mathrm{O}$ (1) there are four organometallic $\left\{\left(\mathrm{C}_{6} \mathrm{H}_{6}\right) \mathrm{Ru}\right\}^{2+}$ fragments which are coordinated asymmetrically to $\alpha$-Keggin type $\left[\mathrm{VNb}_{12} \mathrm{O}_{40}\right]^{15-}$ anion (Fig. 1). The peculiarity of the structure is that only three of such Ru-complex fragments are coordinated to triangular faces of the anion, and the fourth $\left\{\left(\mathrm{C}_{6} \mathrm{H}_{6}\right) \mathrm{Ru}\right\}^{2+}$ unit caps a rectangular face (Fig. 2).

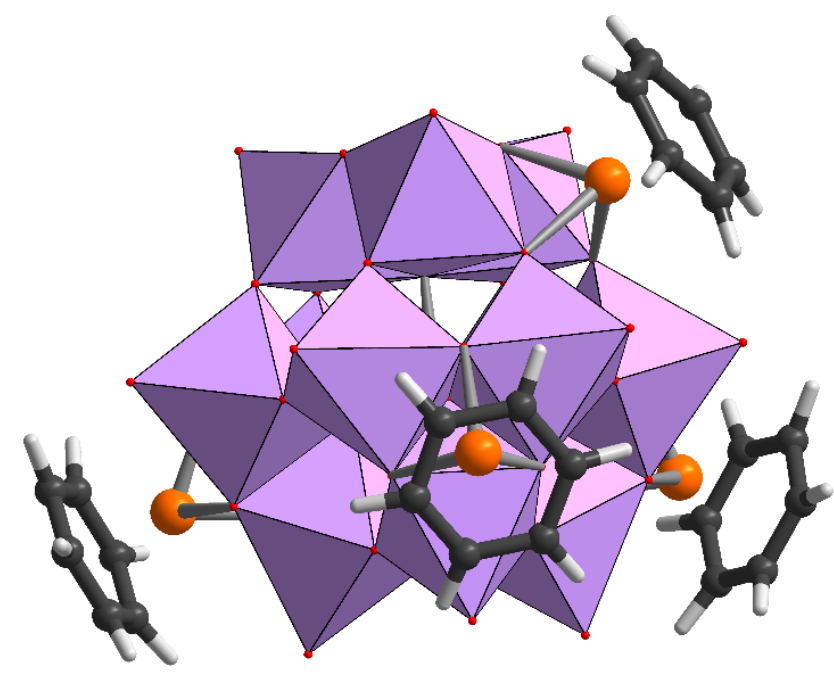

Figure 1. Structure of $\left[\left\{\left(\mathrm{C}_{6} \mathrm{H}_{6}\right) \mathrm{Ru}\right\}_{4} \mathrm{VNb}_{12} \mathrm{O}_{40}\right]^{7-}$.

The coordination to the triangular faces is similar to those observed in the coordination of various $\mathrm{C}_{3 \mathrm{v}}$ organometallic units such as $\left\{\mathrm{M}(\mathrm{CO})_{3}\right\}^{+},\{(\text {arene }) \mathrm{Ru}\}^{2+}$, and $\{\mathrm{Cp} * \mathrm{M}\}^{2+}$ to $\left[\mathrm{M}_{6} \mathrm{O}_{19}\right]^{8-}(\mathrm{M}$ $=\mathrm{Nb}, \mathrm{Ta})$, where similar triangular faces are the only accessible sites for coordination of the complementary pyramidal fragments with three vacant sites. ${ }^{9-12}$ However, the attachment of such a fragment to a rectangular face is unexpected, because one triangular face is left free in this way. Since only three of four oxygen atoms of the rectangular face are used for coordination, it leaves an interesting possibility of $\left\{\left(\mathrm{C}_{6} \mathrm{H}_{6}\right) \mathrm{Ru}\right\}^{2+}$ migration between the four available oxygen ligands within this face. There is, however, no notable difference between the Ru$\mathrm{O}$ bond lengths for these two types of Ru atoms. All Ru-O bond distances lie in a range 2.082(6) - 2.144(6) $\AA$ (Table S2), which agree very well with the values reported for $\mathrm{K}_{4}[\{\mathrm{p}-$ cymene) $\left.\mathrm{Ru}\}_{2} \mathrm{Nb}_{6} \mathrm{O}_{19}\right] \cdot 2 \mathrm{OH}_{2} \mathrm{O} .^{29}$
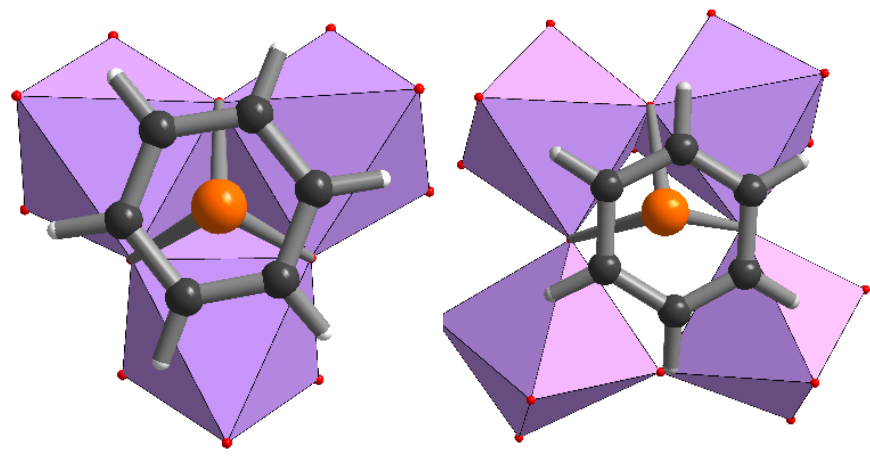

Figure 2. Coordination of $\left\{\left(\mathrm{C}_{6} \mathrm{H}_{6}\right) \mathrm{Ru}\right\}^{2+}$ to the triangular (left) and rectangular faces (right).

It is difficult to explain why the fourth organometallic fragment prefers such site for coordination, which seems to be less favorable from the electrostatic point of view, because the use of the four triangular faces should give more spherical shape of the hybrid anion. We repeatedly tried to isolate the supposed symmetrical isomer, but in all our crystallization batches we found only this unsymmetrical isomer as the single solid phase. Moreover, in the crystal structure of $\mathbf{1}$ we found no additional interactions of the free triangular faces with sodium cations, often observed in hexaniobates. ${ }^{22}$ Indeed, the $\mathrm{Na}^{+}$cations participate instead in the formation of infinite chain-like polycations involving solvate water molecules and only terminal oxoligands of vanadododecaniobate anion.

Such asymmetry should however allow flexible behavior ("hopping" inside the rectangular face) or even lability (coordination/de-coordination) in solution. In order to examine such equilibria, we employed ${ }^{1} \mathrm{H}$ DOSY NMR technique (Fig. 3 ). By applying Stokes-Einstein relation, we could identify in solution two types of species with approximate radii of $8 \AA$ (300 $\left.\mu \mathrm{m}^{2} / \mathrm{s}\right)$ and $10 \AA\left(240 \mu \mathrm{m}^{2} / \mathrm{s}\right)$, which can be attributed to the species with three (the smaller) and four (the larger) coordinated organometallic fragments. This indeed implies the existence of an equilibrium between $\left[\left\{\left(\mathrm{C}_{6} \mathrm{H}_{6}\right) \mathrm{Ru}\right\}_{4} \mathrm{VNb}_{12} \mathrm{O}_{40}\right]^{7-}$ and $\left[\left\{\left(\mathrm{C}_{6} \mathrm{H}_{6}\right) \mathrm{Ru}\right\}_{3} \mathrm{VNb}_{12} \mathrm{O}_{40}\right]^{9-}$. According to ${ }^{1} \mathrm{H}$ DOSY the resonances between $6.1-6.2 \mathrm{ppm}$ correspond to the species with the lower diffusion coefficient and can be thus assigned to $\left\{\left(\mathrm{C}_{6} \mathrm{H}_{6}\right) \mathrm{Ru}\right\}^{2+}$ fragment coordinated to a rectangular face due to their absence in the spectrum assigned to species with higher diffusion coefficient.

We also applied a recently developed straightforward technique to analyze the POM behavior in aqueous ${ }^{30}$ and nonaqueous solutions ${ }^{31}$ based on combination of HPLC and ICP-AES. 
This technique provides independent information about type and composition of each POM component in solution, and this method is valid for evaluation of the supposed equilibrium between the $\left[\left\{\left(\mathrm{C}_{6} \mathrm{H}_{6}\right) \mathrm{Ru}\right\}_{\mathrm{x}} \mathrm{VNb}_{12} \mathrm{O}_{40}\right]^{\mathrm{n}-}$ species with $\mathrm{x}=3$ and $\mathrm{x}=$ 4 in solution.

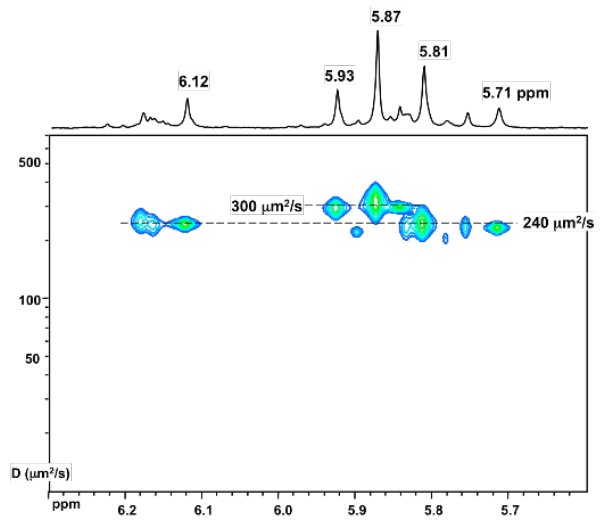

Figure 3. ${ }^{1} \mathrm{H}$ DOSY NMR spectrum of aqueous solution of $\mathbf{1}$.

\section{HPLC-ICP-AES}

A typical HPLC-ICP-AES chromatogram for $\mathrm{CH}_{3} \mathrm{OH}$ solution of $\left[\left\{\left(\mathrm{C}_{6} \mathrm{H}_{6}\right) \mathrm{Ru}\right\}_{4} \mathrm{VNb}_{12} \mathrm{O}_{40}\right]^{7-}$ and $\left[\left\{\left(\mathrm{C}_{6} \mathrm{H}_{6}\right) \mathrm{Ru}\right\}_{3} \mathrm{VNb}_{12} \mathrm{O}_{40}\right]^{9-}$ is shown in Fig. 4.

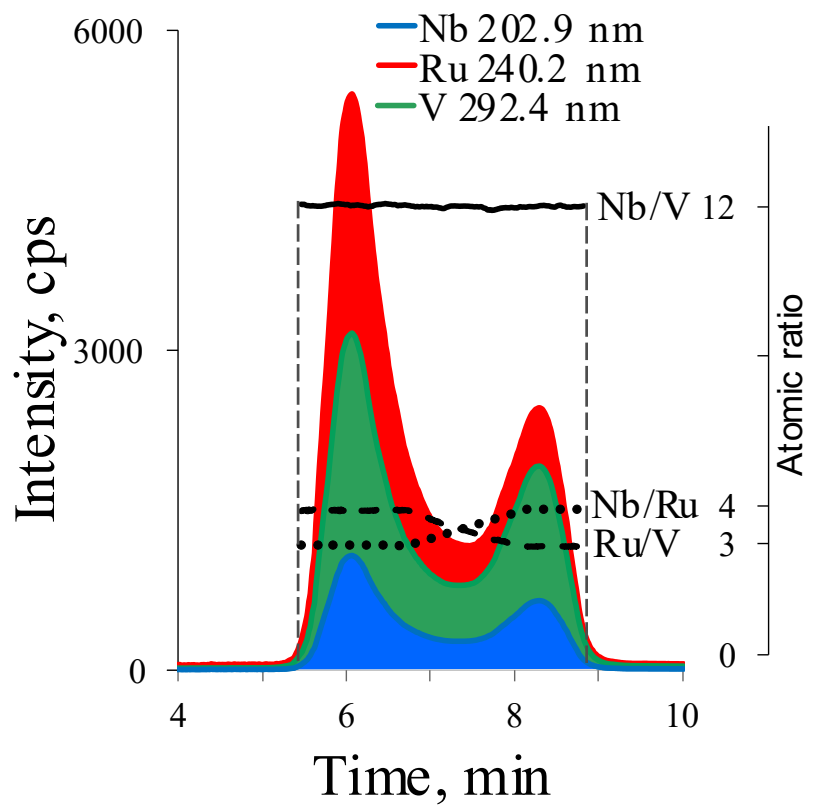

Figure 4. HPLC-ICP-AES chromatogram for $\left[\left\{\left(\mathrm{C}_{6} \mathrm{H}_{6}\right) \mathrm{Ru}\right\}_{4} \mathrm{VNb}_{12} \mathrm{O}_{40}\right]^{7-}$ and $\left[\left\{\left(\mathrm{C}_{6} \mathrm{H}_{6}\right) \mathrm{Ru}_{3} \mathrm{VNb}_{12} \mathrm{O}_{40}\right]^{9-}\right.$ in methanol.

The HPL-ICP-AES data indicate the presence of two peaks, both containing $\mathrm{Nb}, \mathrm{V}$ and $\mathrm{Ru}$ with different atomic ratios (Table S3). There are two species with the same $\mathrm{Nb} / \mathrm{V}$ ratio $=12$, but different $\mathrm{Nb} / \mathrm{Ru}$ ratio ( 3 for the first peak, and 4 for the second) which coexist in an equilibrating mixture and can be attributed to the $\left[\left\{\left(\mathrm{C}_{6} \mathrm{H}_{6}\right) \mathrm{Ru}\right\}_{4} \mathrm{VNb}_{12} \mathrm{O}_{40}\right]^{7-}$ and $\left[\left\{\left(\mathrm{C}_{6} \mathrm{H}_{6}\right) \mathrm{Ru}\right\}_{3} \mathrm{VNb}_{12} \mathrm{O}_{40}\right]^{9-}$ anions. In order to confirm the peak purity of the observed signals we used previously reported approach ${ }^{30}$ and calculated atomic ratio at each point of the HPLC-ICP-AES chromatogram for all pairs of detected spectral lines. Similar to the widely used method for confirming peak homogeneity in HPLC, ${ }^{32}$ our approach takes under consideration overlapped signals to compare peak profiles and calculate signal ratios, while homogeneity is demonstrated by the fact that the ratio of absorbances at two or more specified wavelengths should remain constant throughout the chromatographic peak. We can use spectral lines to discover dissimilarities of peak profiles. Any impurity eluted along with the main peaks will cause a deviation from the horizontal line of the calculated atomic ratio. The atomic ratios of the pairs of spectral lines $\mathrm{Nb} / \mathrm{V}$ and $\mathrm{Nb} / \mathrm{Ru}$ were constant during the entire HPLC-ICP-AES analysis for both peaks. Therefore, it can be argued that the peaks do not contain impurities and there are only two species in equilibrium within the mixture.

\section{HPLC-ESI-MS}

Electrospray ionization mass spectrometry (ESI-MS) is widely used to examine the formation, stoichiometry and speciation of many types of polyoxometalates. ${ }^{33-35}$ The soft ionization conditions employed for ESI-MS are suitable for the investigation of even very large polyoxometalate species. However, simultaneous presence of different POM species in a solution limits the application of the direct ESI-MS technique because the more species are present, the noisier are the spectra with overlapping isotopic patterns for different species, the more complex ESI-MS data interpretation becomes. In this regard, application of HPLC-ESI-MS technique to multicomponent POM mixtures would benefit from preliminary separation of the individual species, followed by subsequent online mass spectral identification of the analytes. We therefore used such coupled techniques to study the equilibrated mixture of $\left[\left\{\left(\mathrm{C}_{6} \mathrm{H}_{6}\right) \mathrm{Ru}_{4} \mathrm{VNb}_{12} \mathrm{O}_{40}\right]^{7-}\right.$ and $\left[\left\{\left(\mathrm{C}_{6} \mathrm{H}_{6}\right) \mathrm{Ru}\right\}_{3} \mathrm{VNb}_{12} \mathrm{O}_{40}\right]^{9-}$. The HPLC-ESI-MS technique is complicated due to the presence of an ion-pairing reagent in the mobile phase of HPLC, required for the separation of negatively charged POM species, which leads to the suppression of the analyte MS signals and source of pollution. ${ }^{36}$ However, tetrabutylammonium (TBA) was successfully used for the analysis of the nucleotides by HPLC-ESI-MS in negativeionization mode by applying low concentrations of the surfactant. ${ }^{37}$ Recently we reported an HPLC based approach for the speciation of the polyoxometalates in the reaction mixture using gradient elution mode with tetrabutylammonium hydroxide $(\mathrm{TBAOH})$ as an ion-pairing reagent. The baseline resolution of the POMs anions was achieved with $\mathrm{TBAOH}$ concentration of $0.04 \%{ }^{30}$ The same separation conditions applied for the combination of HPLC and ESI-MS resulted in the formation of high background ions from the mobile phase containing TBA, $\mathrm{CH}_{3} \mathrm{CN}$ and water and total suppression of analyte MS signals. Reducing the TBAOH concentration to $0.01 \%$ led to the deterioration of the separation resolution, but improved the signal intensity of POM anions, although the 
background ions from the surfactant were still observed. ESI-MS is prone to adduct formation (with water, solvent, protons etc.) which is often regarded as one of the major drawbacks of the technique as it leads to complicated spectra. However, the advantage of the hyphenated HPLC-ESI-MS technique is that the corresponding mass spectrum is recorded at each point of the chromatogram online during a chromatographic separation, which makes it possible to isolate the mass spectrum of each peak and identify all the separated components. Thus, the spectra for both separated peaks, as well as spectrum of the mobile phase, were recorded in order to eliminate the signals of the eluents containing TBA and acetonitrile and to isolate the signals of the POM anion adducts (Fig. 5 and Fig. S1).

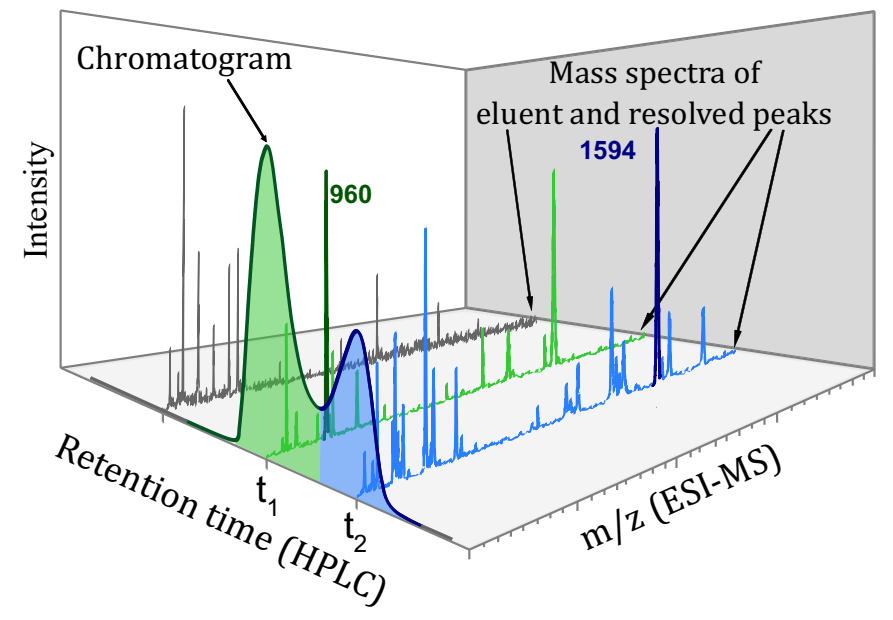

Figure 5. HPLC-UV chromatogram and full scan mass spectra detected by a reversed-phase ion-pair high-performed liquid chromatography/electrospray ionization mass-spectrometry (RP-IP-HPLC/ESI-MS) method for background (eluent) and resolved peak №1 ( $t_{1}=5.5-7 \mathrm{~min}$, green line) and peak №2 $\left(\mathrm{t}_{2}\right.$ $=7.5$ - $9 \mathrm{~min}$, blue line). The dark colored peaks ( $\mathrm{m} / \mathrm{z} 960,1594)$ indicate signals selected for the SIM mode RP-IP-HPLC/ESI-MS analysis (Fig. 4).

ESI-MS spectrum of the eluents (mobile phase without analytes) in negative mode contains 13 signals (Fig. S1), the major one ( $\mathrm{m} / \mathrm{z}$ 853.9) corresponds to a single charged adduct [3TBA ${ }^{+}+$ $\left.4 \mathrm{OH}^{-}+\mathrm{CH}_{3} \mathrm{CN}+\mathrm{H}_{2} \mathrm{O}\right]^{-}$. These signals of the mobile phase are also present in the HPLC-ESI-MS spectra of the resolved peaks corresponding to POM anions and were excluded from the peak assignment to simplify the interpretation of mass spectra (Tables S4 and S5).

All the major signals of the HPLC-ESI-MS spectra of peaks 1 and 2 can be assigned by their $\mathrm{m} / \mathrm{z}$ values and isotopic distributions. Thus, mass spectrum of the first peak shows series of triply- and doubly-charged adducts attributed to $\left[\left\{\left(\mathrm{C}_{6} \mathrm{H}_{6}\right) \mathrm{Ru}_{4} \mathrm{VNb}_{12} \mathrm{O}_{40}+\right.\right.$ $\left.\mathrm{xNa}+\mathrm{yH}+\mathrm{zTBA}+\mathrm{CH}_{3} \mathrm{OH}+\mathrm{CH}_{3} \mathrm{CN}+\mathrm{H}_{2} \mathrm{O}\right]^{3-}$ and $\left[\left\{\left(\mathrm{C}_{6} \mathrm{H}_{6}\right) \mathrm{Ru}\right\}_{4} \mathrm{VNb}_{12} \mathrm{O}_{40}+\mathrm{xNa}+\mathrm{yH}+\mathrm{zTBA}+\mathrm{CH}_{3} \mathrm{OH}+\mathrm{CH}_{3} \mathrm{CN}+\right.$ $\left.\mathrm{H}_{2} \mathrm{O}\right]^{2-}(\mathrm{x}=1-2, \mathrm{y}=1-3, \mathrm{z}=0-2)$. The major signal ( $\mathrm{m} / \mathrm{z}$ 960.4) corresponds to $\left[\left\{\left(\mathrm{C}_{6} \mathrm{H}_{6}\right) \mathrm{Ru}\right\}_{4} \mathrm{VNb}_{12} \mathrm{O}_{40}+\mathrm{Na}+2 \mathrm{H}+\mathrm{TBA}+\mathrm{CH}_{3} \mathrm{OH}+\right.$ $\left.\mathrm{CH}_{3} \mathrm{CN}+\mathrm{H}_{2} \mathrm{O}\right]^{3-}$ (Figs. S2-S5, Table S4).
Similar behavior is observed for the second peak, where mass spectrum shows series of triply- and doubly-charged adducts attributed to $\left[\left\{\left(\mathrm{C}_{6} \mathrm{H}_{6}\right) \mathrm{Ru}_{3} \mathrm{VNb}_{12} \mathrm{O}_{40}+\mathrm{xNa}+\mathrm{yH}+\mathrm{zTBA}+\mathrm{CH}_{3} \mathrm{OH}+\right.\right.$ $\left.\mathrm{nCH}_{3} \mathrm{CN}+\mathrm{H}_{2} \mathrm{O}\right]^{3-}$ and $\left[\left\{\left(\mathrm{C}_{6} \mathrm{H}_{6}\right) \mathrm{Ru}_{3} \mathrm{VNb}_{12} \mathrm{O}_{40}+\mathrm{xNa}+\mathrm{yH}+\mathrm{zTBA}+\right.\right.$ $\left.\mathrm{CH}_{3} \mathrm{OH}+\mathrm{nCH}_{3} \mathrm{CN}+\mathrm{H}_{2} \mathrm{O}\right]^{2-}(\mathrm{x}=1-2, \mathrm{y}=2-5, \mathrm{z}=0-4, \mathrm{n}=1-2)$. The major signal ( $\mathrm{m} / \mathrm{z}$ 1593.9) corresponds to $\left[\left\{\left(\mathrm{C}_{6} \mathrm{H}_{6}\right) \mathrm{Ru}\right\}_{3} \mathrm{VNb}_{12} \mathrm{O}_{40}\right.$ $\left.+\mathrm{Na}+3 \mathrm{H}+3 \mathrm{TBA}+\mathrm{CH}_{3} \mathrm{OH}+\mathrm{CH}_{3} \mathrm{CN}+\mathrm{H}_{2} \mathrm{O}\right]^{2-}$ (Figs. S6-S13, Table $\mathrm{S} 5)$. Interesting to note that in the case of the second POM peak, adducts containing two acetonitrile molecules are formed. Apparently, this can be explained by an increase in the acetonitrile concentration during chromatographic separation with gradient elution (from 30 to $45 \%$ ). The $\mathrm{m} / \mathrm{z}$ values corresponding to the most intense signal for each species, and do not overlap with eluent adducts, were selected for the SIM mode RP-IP-HPLC/ESI-MS analysis (Fig. 6).

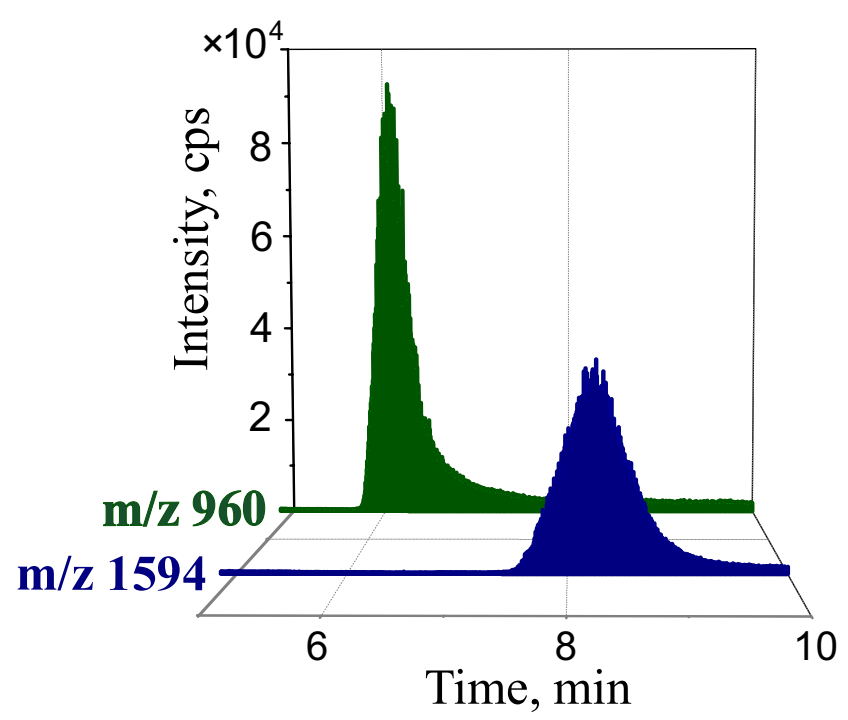

Figure 6. Simultaneous SIM mode RP-IP-HPLC/ESI-MS analysis of $\quad\left[\left\{\left(\mathrm{C}_{6} \mathrm{H}_{6}\right) \mathrm{Ru}_{4} \mathrm{VNb}_{12} \mathrm{O}_{40}\right]^{7-} \quad(\mathrm{m} / \mathrm{z} \quad 960) \quad\right.$ and $\left[\left\{\left(\mathrm{C}_{6} \mathrm{H}_{6}\right) \mathrm{Ru}\right\}_{3} \mathrm{VNb}_{12} \mathrm{O}_{40}\right]^{9-}(\mathrm{m} / \mathrm{z} 1594)$ 


\section{Isolation of $\mathrm{Na}_{5}\left[\alpha-\left\{\left(\mathrm{C}_{6} \mathrm{H}_{6}\right) \mathrm{Ru}\right\}_{5} \mathrm{VNb}_{12} \mathrm{O}_{40}\right] \cdot 16 \mathrm{H}_{2} \mathrm{O}$ (2)}

The methanolic solution of $\mathbf{1}$, containing mixture of $\left[\left\{\left(\mathrm{C}_{6} \mathrm{H}_{6}\right) \mathrm{Ru}\right\}_{4} \mathrm{VNb}_{12} \mathrm{O}_{40}\right]^{7-}$ and $\left[\left\{\left(\mathrm{C}_{6} \mathrm{H}_{6}\right) \mathrm{Ru}\right\}_{3} \mathrm{VNb}_{12} \mathrm{O}_{40}\right]^{9-}$, was transferred to the chromatographic column filled with silica gel. The choice of methanol as eluent gave a single brown fraction which was collected and evaporated in air. The solid residue was extracted by minimal amount of water. Slow diffusion of $i-\mathrm{PrOH}$ into the aqueous extract produced a crop of orange crystals which were studied by SCXRD. Surprisingly, in the crystal structure we detected a new anion with five coordinated $\left\{\left(\mathrm{C}_{6} \mathrm{H}_{6}\right) \mathrm{Ru}\right\}^{2+}$ groups (Fig. 7). The main geometrical parameters are summarized in Table S2. In this case the hybrid anion has mirror plane symmetry crossing one $\left\{\left(\mathrm{C}_{6} \mathrm{H}_{6}\right) \mathrm{Ru}\right\}^{2+}$ capping group. Three $\left\{\left(\mathrm{C}_{6} \mathrm{H}_{6}\right) \mathrm{Ru}\right\}^{2+}$ groups are coordinated to triangular faces in a regular manner and two organometallic groups are bonded to rectangular faces. Ru-O bond distances lie in the typical range (Table S2).

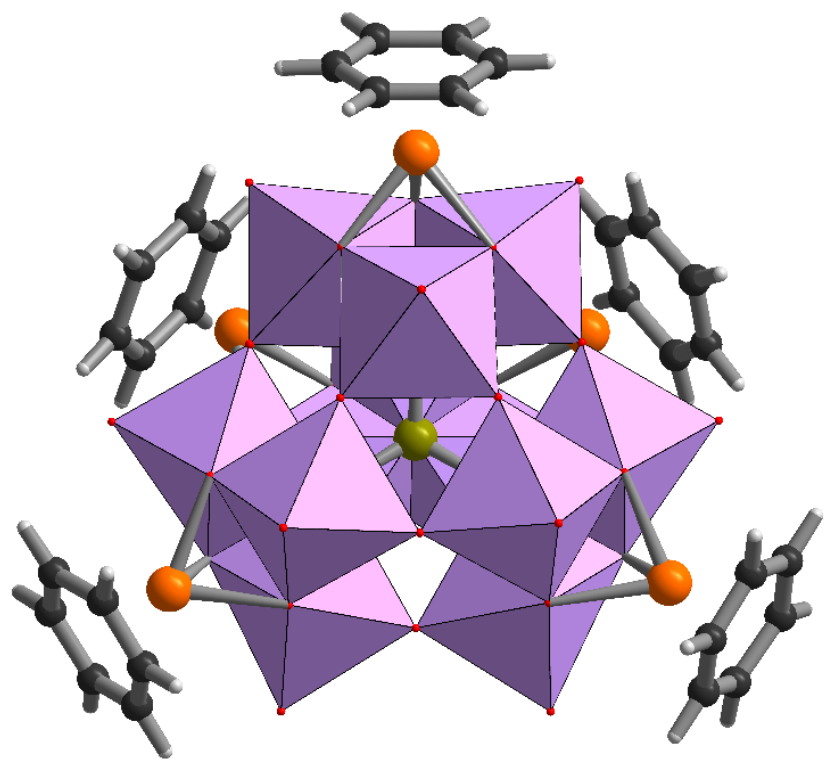

Figure 7. The structure of $\left[\alpha-\left\{\left(\mathrm{C}_{6} \mathrm{H}_{6}\right) \mathrm{Ru}\right\}_{5} \mathrm{VNb}_{12} \mathrm{O}_{40}\right]^{5-}$ hybrid anion.

Taking into account absence of such type anion in the initial reaction mixture, we can suppose that this interesting transformation took place on the silica gel surface during elution. We can suggest that during decoordination of a Ru cap produces a highly charged species like $\left[\left\{\left(\mathrm{C}_{6} \mathrm{H}_{6}\right) \mathrm{Ru}\right\}_{2} \mathrm{VNb}_{12} \mathrm{O}_{40}\right]^{11-}$ which remains tightly attached to $\mathrm{SiO}_{2}$, while the released $\left\{\left(\mathrm{C}_{6} \mathrm{H}_{6}\right) \mathrm{Ru}\right\}^{2+} \quad$ converts $\quad\left[\left\{\left(\mathrm{C}_{6} \mathrm{H}_{6}\right) \mathrm{Ru}_{4} \mathrm{VNb}_{12} \mathrm{O}_{40}\right]^{7-} \quad\right.$ into $\left[\left\{\left(\mathrm{C}_{6} \mathrm{H}_{6}\right) \mathrm{Ru}\right\}_{5} \mathrm{VNb}_{12} \mathrm{O}_{40}\right]^{5-}$.

The bulk solid sample was characterized by elemental analysis revealing a chemical composition of $\mathrm{Na}_{5}[\alpha-$ $\left.\left\{\left(\mathrm{C}_{6} \mathrm{H}_{6}\right) \mathrm{Ru}\right\}_{5} \mathrm{VNb}_{12} \mathrm{O}_{40}\right] \cdot 16 \mathrm{H}_{2} \mathrm{O}$ (2). The solution behaviour of this complex was studied by ${ }^{1} \mathrm{H}$, and ${ }^{51} \mathrm{~V}$ NMR (Figs. S15 and S16) and
HR-ESI-MS (Fig. S18, Table S6). ${ }^{51} \mathrm{~V}$ NMR spectrum demonstrated single line at $-467.3 \mathrm{ppm}$, while ${ }^{1} \mathrm{H}$ NMR spectrum showed different species in equilibrium. The HR-ESIMS data at concentration of ca. $10^{-6} \mathrm{M}$ showed peaks corresponding to $\left[\left\{\left(\mathrm{C}_{6} \mathrm{H}_{6}\right) \mathrm{Ru}_{5} \mathrm{VNV}_{12} \mathrm{O}_{40}\right]^{5-}\right.$ and $\left[\left\{\left(\mathrm{C}_{6} \mathrm{H}_{6}\right) \mathrm{Ru}\right\}_{4} \mathrm{VNb}_{12} \mathrm{O}_{40}\right]^{7-}$ anions associated with cations and solvent molecules.

\section{Conclusions}

The $\left[\mathrm{VNb}_{12} \mathrm{O}_{40}\right]^{15-}$ does not exist as a free anion, and has always to be stabilized by at least two additional metal addenda. Moreover, in solution it always equilibrates with oligomeric species. In this work we used $\mathrm{Na}_{9} \mathrm{H}_{4}\left[\mathrm{VNb}_{12} \mathrm{O}_{40}\left\{\mathrm{NbO}\left(\mathrm{CO}_{3}\right)\right\}_{2}\right]$ as easily available in situ source of $\left[\mathrm{VNb}_{12} \mathrm{O}_{40}\right]^{15-}$ to react with coordination complexes of transition metal cations. With $\left[\left(\mathrm{C}_{6} \mathrm{H}_{6}\right) \mathrm{RuCl}_{2}\right]_{2}$ in molar ratio of $\left\{\mathrm{VNb}_{12}\right\}:\left\{\left(\mathrm{C}_{6} \mathrm{H}_{6}\right) \mathrm{Ru}\right\}=1: 4$, it gives $\left[\alpha-\left\{\left(\mathrm{C}_{6} \mathrm{H}_{6}\right) \mathrm{Ru}_{4} \mathrm{VNb}_{12} \mathrm{O}_{40}\right]^{7-}\right.$ where $\left\{\left(\mathrm{C}_{6} \mathrm{H}_{6}\right) \mathrm{Ru}\right\}^{2+}$ unexpectedly coordinates to both triangular and rectangular faces, forming asymmetrical isomer in the solid state. In water one Ru cap is released to form 4:1 and 3:1 complexes in dynamic equilibria. The combination of HPLC-ICP-AES and HPLC-ESI-MS has proven to be a valuable tool for the investigation of the POM species coexisting in an equilibrating mixture. It should be noted that these analytical separation tools together with DOSY NNM were firstly applied to the solution studies of polyoxoniobate based complexes. Attempts to separate the $4: 1$ and $3: 1$ species by chromatography on silica gel led to the formation of a new [ $\alpha$ $\left.\left\{\left(\mathrm{C}_{6} \mathrm{H}_{6}\right) \mathrm{Ru}\right\}_{5} \mathrm{VNb}_{12} \mathrm{O}_{40}\right]^{5-}$ hybrid anion. This symmetrical anion with 5 coordinated organometallic groups is characterized by SCXRD.

Hence we demonstrated that $\left[\mathrm{VNb}_{12} \mathrm{O}_{40}\right]^{15-}$, acting as polytopic (three, tetra, and pentatopic) ligand can coordinate to up to five $\left\{\left(\mathrm{C}_{6} \mathrm{H}_{6}\right) \mathrm{Ru}\right\}^{2+}$ groups locating into triangular and rectangular faces. Such a high coordination capacity of plenary Keggin anions is unique. We believe that $\left[\mathrm{VNb}_{12} \mathrm{O}_{40}\right]^{15-}$ and its $\mathrm{Si}$ - and $\mathrm{P}$-centered analogues can provide a new family of heterometalrich polyoxometalates which can exist as isolated molecular species or serve inorganic node for the contraction of extended frameworks.

\section{Author Contributions}

AAM - Investigation, VVV - Investigation, DGS - Investigation, VVY Investigation, NBK - Investigation, MH - Investigation, PAA - Project administration, MNS - Supervision.

\section{Conflicts of interest}

There are no conflicts to declare. 


\section{Acknowledgements}

This work was supported by Russian Science Foundation (grant number RSF 19-73-10027). MH thanks LIA FRANCE-RUSSIA CLUSPOM and financial supports from LabEx CHARMMMAT (grant number ANR-11-LBX-0039).

\section{Notes and references}

A. Lombana, C. Rinfray, F. Volatron, G. Izzet, N. Battaglini, S. Alves, P. Decorse, P. Lang and A. Proust, J. Phys. Chem. C, 2016, 120, 2837-2845.

G. Izzet, B. Abécassis, D. Brouri, M. Piot, B. Matt, S. A. Serapian, C. Bo and A. Proust, J. Am. Chem. Soc., 2016, 138, 5093-5099.

3 L. Huder, C. Rinfray, D. Rouchon, A. Benayad, M. Baraket, G. Izzet, F. Lipp-Bregolin, G. Lapertot, L. Dubois, A. Proust, L. Jansen and F. Duclairoir, Langmuir, 2016, 32, 4774-4783. G. Rousseau, E. Rivière, A. Dolbecq, J. Marrot, O. Oms and P. Mialane, Eur. J. Inorg. Chem., 2013, 2013, 1793-1798. J. Fielden, J. M. Sumliner, N. Han, Y. V. Geletii, X. Xiang, D. G. Musaev, T. Lian and C. L. Hill, Chem. Sci., 2015, 6, 55315543. Y. P. Liu, S. F. Zhao, S. X. Guo, A. M. Bond, J. Zhang, G. Zhu, C. L. Hill and Y. V. Geletii, J. Am. Chem. Soc., 2016, 138,

7 P. Putaj and F. Lefebvre, Coord. Chem. Rev., 2011, 255, 1642-1685.

8 S. N. Bernstein and K. R. Dunbar, Angew. Chemie Int. Ed. English, 1992, 31, 1360-1362. A. V Besserguenev, M. H. Dickman and M. T. Pope, Inorg. Chem., 2001, 40, 2582-2586. P. A. Abramov, M. N. Sokolov, S. Floquet, M. Haouas, F. Taulelle, E. Cadot, E. V. Peresypkina, A. V. Virovets, C. Vicent, N. B. Kompankov, A. A. Zhdanov, O. V. Shuvaeva and V. P. Fedin, Inorg. Chem., 2014, 53, 12791-12798. P. A. Abramov, M. N. Sokolov, A. V. Virovets, S. Floquet, M. Haouas, F. Taulelle, E. Cadot, C. Vicent and V. P. Fedin, Dalton Trans., 2015, 44, 2234-2239. P. A. Abramov, T. P. Zemerova and M. N. Sokolov, J. Clust. Sci., 2017, 28, 725-734. P. A. Abramov, C. Vicent, N. B. Kompankov, A. L. Gushchin and M. N. Sokolov, Eur. J. Inorg. Chem., 2016, 2016, 154160. P. A. Abramov, C. Vicent, N. B. Kompankov, J. A. Laricheva and M. N. Sokolov, RSC Adv., 2016, 6, 20240-20246. V. Artero and A. Proust, Eur. J. Inorg. Chem., 2000, 2000, 2393-2400. R. Bakri, A. Booth, G. Harle, P. S. Middleton, C. Wills, W. Clegg, R. W. Harrington and R. J. Errington, Chem. A. V. Anyushin, A. I. Smolentsev, D. A. Mainichev, C. Vicent, A. L. Gushchin, M. N. Sokolov and V. P. Fedin, Chem. Commun., 2014, 50, 9083-9085. and M. N. Sokolov, Russ. J. Inorg. Chem., 2017, 62, 3972617-2628. Commun., 2012, 48, 2779.

403.
19

22
Kompankov, A. L. Gushchin, E. Benassi, P. A. Abramov and M. N. Sokolov, Inorg. Chem., 2020, 59, 2116-2120.

S. A. Adonin, N. V. Izarova, C. Besson, P. A. Abramov, B. Santiago-Schübel, P. Kögerler, V. P. Fedin and M. N. Sokolov, Chem. Commun., 2015, 51, 1222-1225. M. Nyman, Science (80-. )., 2002, 297, 996-998. M. Nyman, Dalton Trans., 2011, 40, 8049-8058. G. Guo, Y. Xu, J. Cao and C. Hu, Chem. Commun. (Camb)., 2011, 47, 9411-9413.

J. H. Son, C. A. Ohlin, E. C. Larson, P. Yu and W. H. Casey, Eur. J. Inorg. Chem., 2013, 1748-1753.

J.-H. Son, C. A. Ohlin, R. L. Johnson, P. Yu and W. H. Casey, Chem. Eur. J., 2013, 19, 5191-5197.

Z.-Y. Zhang, J. Peng, Z.-Y. Shi, W.-L. Zhou, S. U. Khan and H.S. Liu, Chem. Commun. (Camb)., 2015, 51, 3091-3.

Z. Liang, Y. He, Y. Qiao, P. Ma, J. Niu and J. Wang, Inorg. Chem., 2020, 59, 7895-7899.

P. A. Abramov, A. T. Davletgildeeva, N. K. Moroz, N. B. Kompankov, B. Santiago-Schübel and M. N. Sokolov, Inorg. Chem., 2016, 55, 12807-12814.

D. Laurencin, R. Thouvenot, K. Boubekeur and A. Proust, Dalton Trans., 2007, 1334-1345.

O. V. Shuvaeva, A. A. Zhdanov, T. E. Romanova, P. A. Abramov and M. N. Sokolov, Dalton Trans., 2017, 46, 3541-3546.

A. V. Chupina, V. Shayapov, A. S. Novikov, V. V. Volchek, E. Benassi, P. A. Abramov and M. N. Sokolov, Dalton Trans., 2020, 49, 1522-1530.

M. Stahl, Agil. Technol., 2003, 8, 5988-8647.

L. Fan, J. Cao and C. Hu, RSC Adv., 2015, 5, 83377-83382. H. N. Miras, E. F. Wilson and L. Cronin, Chem. Commun., 2009, 1297-1311.

E. F. Wilson, H. N. Miras, M. H. Rosnes and L. Cronin, Angew. Chemie - Int. Ed., 2011, 50, 3720-3724.

M. C. García, J. Chromatogr. B Anal. Technol. Biomed. Life Sci., 2005, 825, 111-123.

E. Witters, W. Van Dongen, E. L. Esmans and H. A. Van Onckelen, J. Chromatogr. B Biomed. Appl., 1997, 694, 5563. 